\title{
PARTISIPASI MASYARAKAT DALAM PELESTARIAN \\ TENUN IKAT DI DESA ENSAID PANJANG \\ KECAMATAN KELAM PERMAI
}

\author{
Antonius Erwandi \\ Fakultas Ilmu Sosial Dan Ilmu Politik Universitas Kapuas Sintang \\ Jalan Oevang Oeray 92 Sintang \\ Email : erwandi.unka@gmail.com
}

\begin{abstract}
Abstrac
Public participation is needed in supporting the craftsmen to continue working in the process of making ikat cloth. The low level of participation leads to the decreasing of craftsmen motivation in producing ikat cloth so that the economic potential that is part of the tourism potential of the region is also not maximized to support the community's economy.
\end{abstract}

Keywords: Participation, Society, Ikat Woven Fabrics

\footnotetext{
Abtrak

Partisipasi masyarakat sangat diperlukan dalam menunjang pengerajin untuk terus berkarya dalam proses pembuatan kain tenun ikat. Rendahnya tingkat partisipasi menyebabkan menurunnya motivasi pengerajin dalam memperoduksi kain tenun ikat sehingga potensi ekonomi yang menjadi bagian dari potensi wisata daerah juga belum maksimal untuk menunjang perekonomian masyarakat.
}

Kata Kunci : Partisipasi, Masyarakat, Kain tenun Ikat.

\section{Latar Belakang}

Pembangunan nasional merupakan keseluruhan dari pembangunan yang meliputi daerah-daerah sehingga pembangunan daerah dapat dikatakan sebagai bagian dari pembangunan nasional itu sendiri. Pembangunan daerah tentunya sesuai dengan sistem perencanaan pembangunan yang telah di musyawarahkan melalui tahapantahapan Musrenbang mulai dari tingkat desa sampai pada tingkat Kabupaten. Didalam rencana pembangunan daerah khususnya pembangunan desa akan sangat terarah jika pembangunan tersebut mengacu pada pengembangan potensi yang dapat diarahkan untuk meningkatkan kesejahteraan masyarakat setempat

Pola pengembangan potensi yang sudah ada dan dapat bernilai ekonomis tentunya tidak akan maksimal tanpa adanya keterlibatan berbagai pihak dan yang paling 
utama yaitu pemerintah daerah. peran pemerintah daerah dapat diwujudkan dalam berbagai program pengembangan dengan disertai pendampingan serta bantuan dana atau biaya. Hal ini perlu menjadi perhatian mengingat keterbatasan masyarakat dalam memproduksi hasil karya tradisional yang mengakibatkan tingkat produktivitas belum dapat sepenuhnya memeuhi permintaan pasar. Pada sisi lainnya untuk lebih menciptakan tingkat produksi kain tenun diperlukan juga bantuan prasarana serta relasi pasar yang tetap dan bahkan jika memungkinkan dapat mencapai tingkat penjualan ke negara luar, secara tidak langsung bagi daerah juga akan meningkatkan pendapatan asli daerah.

Kain tenun ikat yang di produksi oleh pengarajin tradisional di Desa Ensaid Panjang Kecamatan Kelam Permai Kabupaten Sintang merupakan keahlian yang sudah ada sejak dulu dan terus dilestarikan oleh generasi mudah hingga saat ini. Keunikan kain tenun ikad yaitu terbuat dari bahan-bahan alami yang diperoleh dari daerah sekitarnya dan memiliki corak atau motif yang melambangkan ciri khas masyarakat Dayak, sistem pembauatan kain tenun ikad juga menggunakan tenun tradisional atau manual sehingga keasliannya masih sangat terjamin.

Dewasa ini di rasakan masih lemahnya tingkat partisipasi masyarakat terhadap prospek tersebut menyebabkan kerajinan kain tenun ikat hanya bersifat sesaat jika ada gelar-gelar budaya dan belum menjadi produk unggulan yang dapat memberikan manfaat bagi seluruh masayrakat yang terlibat di dalamnya. Dengan demikian dapat dikatakan bahwa partisipasai masyarakat luas di daerah kabupaten Sintang dan secara khusus partisipasi pemerintah belumlah maksimal sehingga diperlukan konsep dan strategi menuju terciptanya partisipasi yang utuh dari seluruh pihak masyarakatnya. rendahnya partisipasi juga dapat menurunkan tingkat motivasi para pengerajin karena kurangnya hubungan kerjasama yang dapat memberikan jaminan terhadap produk yang akan dipasarkan kepada masyarakat.

\section{Pembahasan}

\section{A. Deskripsi Wilayah Penelitian}

Desa Ensaid panjang berada di wilayah kecamatan Kelam Permai Kabupaten Sintang, adapun batas-batas administratif wilayah yaitu :

a. Sebelah Utara berbatasan dengan Desa Sungai Maram

b. Sebelah Selatan berbatasan dengan Desa Empaci

c. Sebelah Timur berbatasan dengan Desa Merpak

d. Sebelah Barat berbatasan dengan Desa Baning Panjang

Berdasarkan letak administrasi tersebut dapat diketahui bahwa Desa ensaid 
Panjang dapat dikunjungi melalui beberapa jalur baik jalur darat maupun jalur angkutan Sungai yang berada di desa Sungai Maram karena Desa Sungai Maram terletak di tepian Sungai Kapuas sehingga dengan kondisi yang mudah terjangkau tersebut memungkinkan masyarakat dengan mudah mengunjungi daerah wisata alam di desa Ensaid Panjang.

Mata pencaharian masyarakat di Desa Ensaid Panjang umumnya sebagai petani sebagaimana daerah perdesaan di Kalimantan Barat pertanian yang ditekuni masyarakat yaitu pertanian gilir balik atau berladang, hal ini merupakan salah satu inspirasi dalam menumbuhkan kebudayaan masyarakat dan sampai saat ini masyarakat di Desa Ensaid Panjang masih memegang kebudayaan yang diwariskan sejak dahulu karena kebudayaan menjadi pedoman dalam bertindak dan membangun kehidupan bersama. demikian juga dengan kerajinan kain tenun ikad yang menjadi salah satu warisan budaya dalam masyarakat terus dijalankan dan ditekuni sebagai bagian dari mendapatkan pengahasilan ekonomi, oleh karenya pemerintah Kabupaten Sintang berupaya menjadikan desa Ensaid panjang sebagai daerah wisata alam yang berbasis budaya.

Desa Ensaid Panjang sebagai desa wisata memerlukan perhatian pemerintah dalam membangun infrastruktur serta pembinaan bagi sumber daya manusianya sehingga dengan adanya perhatian dan pembinaan terhadap masyarakt akan tumbuh tingkat kesadaran untuk berpartisipasi kepada daerah selain itu manfaat dari tingginya partisipasi masyarakat akan menciptakan suasana yang asri dilingkugsan sosial sehingga kesan budaya dan alamiah dari desa wisata akan sangat dirasakan. Kain tenun ikat sebagai bagian dari daya terik hasil budaya masyarakat memiliki nilai yang sangat tinggi dan hal itu merupakan potensi yang harus dikembangkan melalui sistemsistem informasi serta ekspos yang beragam kepada publik mengingat perkembangan teknologi dan informasi saat ini memudahkan konsumen dalam memperoleh produk-produk hasil kerejinan masyarakat.

\section{B. Bentuk Partisipasi Masyarakat}

Berdasrkan hasil wawancara dengan Kepala Desa Ensaid Panjang Kecamatan Kelam Permai Kabupaten Sintang diperoleh infomasi bahwa salah satu program wisata daerah Kabupaten Sintang yaitu mengembangkan potensi wisata kain tenun ikat yang sudah lama menjadi produk unggulan di desa ensaid Pangjang selama ini. Program pemerintah menurutnya tentu akan berjalan dengan baik jika terdapat partisipasi yang tinggi dari semua pihak termasuklah 
masyarakat sekitarnya. Partisipasi masyarakat besar perannya dalam memberikan semangat kepada pengarajin tenun ikad untuk terus berkarya secara nayata terlebih lagi dengan kondisi komoditas hasil perkebunan di masyarakat mengalami penurunan harga ditingkat pasar.

Berdasarkan hasil wawancara dengan Kepala Desa Ensaid Panjang di peroleh informasi bahwa selama ini bentuk partisipasi masyarakat terhadap keberadaan tenun ikad beraneka ragam sehingga hasil-hasil tenun ikat bukan hanya dari satu orang saja akan tetapi dari beberapa orang yang dalam prosesnya membentuk kelompok-kelompok pengarajin. Pada tataran pemuda partisipasi juga terlihat dari keterlibatan untuk memasarkan secara individu melalui jaringan masing-masing dan ini terus berlangsung hingga saat ini.

Selanjutnya dipaparkan oleh Kepala Desa Ensaid Panjang bahwa aspirasi dalam bentuk ide dan konsep-konsep sebagai upaya melestarikan seni menenun juga terus dilakukan dan umumnya dipelopori oleh kalangan pemuda. Oleh karena itu dapat dikatakan partisipasi yang dilakukan oleh seluruh elemen masyarakat di Desa Ensaid Panjang dalam bentuk terlibat langsung dan tidak langsung, yang tidak langsung yaitu dnegan adanya keterlibatan dalam rapatrapat BPD yang diusulkan secara resmi dan tujuannya pada pemerintah.

Secara lebih spesifik dikemukakan oleh Kepala Desa dengan adanya partisipasi masyarakat dari berbagai bentuk kerajinan tenun ikad masih menjadi andalan dalam upaya menambah dan meningkatkan perekonomian karena jika dilihat dari kehidupan masyarakat memang mengandalkan hasil produk tenun ikad. Keterlibatan masyarakat dari berbagai macam unsur terbukti dapat membangkitkan semangat para pengarajin walaupun terkadang dari segi harganya masih relatif murah karena proses pembuatannya masih di tenun secara manual.

Berlandaskan pada hasil-hasil wawancara dengan Kepala Desa Ensaid Panjang tersebut dapat di deskripsikan bahwa kelestarian kain tenun ikad sangat kuat dipengaruhi oleh adanya partisipasi masyarakat sedangkan perhatian dari pemerintah dapat dikatakan relatif baru seperti dengan adanya kebijakan terhadap program daerah wisata. partisipasi dalam hal ini merupakan modal dasar dan juga potensi yang dapat dikembangkan sehingga dengan adanya peran pemerintah semakin memberikan dorongan yang kuat bagi masyarakat dan juga bagi pengarajin tenun ikad di Desa Ensaid Panjang. Sebagimana diketahui bahwa modal pembangunan yang paling penting yaitu kepedulian masyarakatnya yang memiliki 
nilai-nilai kebudayaan.

Selanjutnya Ketua Badan

Permusyawaratan Desa Ensaid Panjang Kecamatan Kelam Permai Kabupaten Sintang menjelaskan jika berbicara tentang partisipasi masyarakat di desa Ensaid terhadap kerajinan kain tenun ikad sudah sangat tinggi hal ini tentunya dapat dijelaskan dari banyak sudut pandang seperti keterlibatan masyarakat dalam menjaga kualitas kain tenun ikad, keterlibatan masyarakat dalam mengikuti berbagai pameran budaya dan juga keterlibatan masyarakat dalam memberikan konsepkonsep pengembangan model kain tenun ikad yang selama ini sudah dapat dipasarkan secara bebas.

Berikutnya disampaikan juga oleh Ketua BPD Desa Ensaid Panjang keterlibatan masyarakat merupakan potensi yang menjadi dasar bagi pemerintah desa memberikan alokasi untuk melestarikan budaya pembuatan kain tenun yang sampai dengan saat ini masih manual dan juga dari bahan-bahan baku yang masih alami asli dari alam yang tersedia di sekitar Desa ensai Panjang. Dengan demikian bentuk partisipasi yang sangat komplek diberikan masyarakat selama ini yang membuat kerajinan tradisional tenun ikad dapat bertahan dan dapat menjadi komoditas andalan bagi desa Ensaid saat ini. Jika dibandingkan dengan perkembangan kerajinan tenun yang lebih modern tentunya belumlah dapat menghasilkan dalam jumlah yang banyak namun dalam mensiasati hal tersebut dibuatlah kelompok-kelompok pengrajin yang dapat memproduksi sesuai pesanan dari pembeli dan hal itu dapat tercukupi.

\section{Selanjutnya menurut Ketua BPD}

Desa Ensaid Panjang bahwa peran sektor swasta atau non pemerintah juga cukup besar dalam menjaga dan meningkatkan semangat para pengrajin tenun ikad ini seperti keterlibatan Lembaga Swadaya Masyarakat (LSM) yang selalu memberikan bantuanbantuan baik dalam bentuk penyuluhan dan juga modal bahkan akses untuk pemasaran, diceritakannya sebelum pemerintah memberikan perhatiannya pihak dari yayasan pastoran sudah menjadi mitra bagi masyarakat dalam memasarkan hasil produksi tenun ikad, hal ini tentunya bentuk partisipasi yang sangat membantu masyarakat untuk terus bekerja di bidang kerajinan tradisional tersebut.

Berangkat dari hasil wawancara yang terhimpun melalui Ketua BPD tersebut dapalah dijelaskan bahwa peran masyarakat dalam berbagai bentuk yang tujuannya untuk menjaga, melestarikan dan meningkatkan produk kain tenun ikad selama merupakan kepercayaan bagi dunia luar seperti LSM dan juga pemerintah dan hal inilah yang 
sangat membantu dalam proses perjalanan berikutnya bagi para pengrajin sehingga masih tetap melakukan kegiatannya dalam membuat kain tenun ikad dan dalam proses pemasaran juga sudah dapat dikatakan memiliki nilai ekonomi yang dapat menopang perekonomian rumah tangga. Sebagaimana diketahui bahwa keberlanjutan dari kerajinan tenun ikad memperoleh dukungan dari semua elemen dan dalam hal ini partisipasi masyarakat juga semakin meningkat yaitu dengan menjaga lingkungan sosial disekitarnya agar tetap kondusif seiring dengan berjalannya program -program pengembangan daerah wisata dan daya dukungnya yang bernilai tinggi.

Berikutnya hasil wawancara dengan Ketua Adat Desa Ensaid Panjang Kecamatan Kelam Permai Kabupaten Sintang diperoleh informasi bahwa kerajinan kain tenun ikad di desa ensaid panjang pada mulanya menurut kisah dari sejak dulu hanya untuk berbagai keperluan upacara adat, sehingga masyarakat desa ensaid memiliki alat tenun yang dibuat secara manual, untuk mengerjakan pekerjaan tersebut umumnya ibu rumah tangga dan hal itu bukan merupakan pekerjaan pokok masyarakatnya. Pekerjaan pokok seperti pada umumnya masyarakat mengandalkan hasil perkebunan karet dan juga berladang. Dalam perkembangan berikutnya ketrampilan tersebut selalu di turunkan kepada anak- anak sampai dengan saat ini masih terus di wariskan.

Di kisahkan lebih lanjut bahwa pewarisan ketrampilan memproduk kain tenun ikad saat ini merupakan hal yang cukup unik dimana minat dan ketertarikan masyarakat sudah cukup tinggi, namun terlepas dari hal tersebut tentunya keberadaan kerajinan tradisional dimanapun tidak aka nada jika tidak adanya kemauan dari generasi muda untuk terlibat dalam berbagai bentuk. demikian juga di desa ensaid saai ini kerajinan menenun kain tenun ikad sudah dilakukan oleh kalangan pemuda dan bahkan kaum pria yang terorganisir dalam kelompok pengarajin.. Menurut Ketua adat desa Ensaid panjang partisipasi apapun bentuknya tentunya tidak akan banyak berarti tanpa daya dukung dari pemerintah daerah karena keberadaan kerajinan atau hasil kerajinan harus menjadi sumber ekonomi bagi masyarakat, walaupun tidak utama dan jika memungkinkan harus menjadi utama karena akan menciptakan peluang kerja yang dapat menyerap banyak tenaga kerja.

Berbicara tentang partisipasi secara umum menurut pandangan Ketua Adat bahwa seluruh masyarakat di kabupaten Sintang atau di sekitarnya harus terus memberikan dukungan dan andil yang baik kepada potensi wisata tradisional seperti hal kerajinan tenun 
ikad ini, karena paling tidak pasaran kain tenun ikad ada di kota Sintang dan sekitarnya sehingga dengan kondisi yang baik tersebut dapat memberikan kepercayaan kepada dunia luar atau daerah luar untuk tertarik terhadap kain tenin ikad. Hal itulah yang harus ditemukan strateginya oleh pemerintah di satu sisi kerajinan tersebut tentunya harus tetap berkualitas dan alami dari bahan-bahan alam.

Berdasarkan dari hasil wawancara yang terhimpun dari Ketua adat dapat dideskripsikan bahwa partisipasi masyarakat dalam melestarikan kain tenun ikad tidak dapat dipisahkan dari sejarah panjang yang telah dilalui sampai dengan saat ini. keberadaan potensi kain tenun ikad tentunya sangat tergantung pada masyarakat setempat untuk menjadikannya sebagai potensi wisata yang bernilai ekonomi, permasalahan yang dihadapi selama ini berkenaan dengan akses pasar dan harga ditingkat penjualan dan untuk itu diperlukan adanya kepercayaan masyarakat sekitar Kabupaten Sintang sebagai titik awal dari informasi bagi daerah luar serta adanya dukungan pemerintah yang bertujuan meningkatkan produk tersebut menjadi produk unggulan dan pada akhirnya dapat dijadikan sebagai solusi dalam pembangunan berbasis budaya yang juga dapat dijadikan sebagai penyerap tenaga kerja pada tingkat daerah desa pada masa-masa yang akan datang.
Sektor wisata akan terus berkembang dan dapat dijadikan sebagai harapan bagi masyarakatnya tentunya tidak terlepas keterkaitan sistem-sistem di dalam pemberdayaan generasi muda hal ini tentunya harus dilandasi dari bentuk partisipasi dari dalam dirinya yaitu kesadaran akan pentingnya kebudayaan dan potensi budaya untuk kemajuan hidup dan perekonomian masyarakat dan pemerintah desa. Tujuan bersama juga harus dilandasi dengan komitmen yang kuat dari semua pihak karena kebudayaan akan sia-sia jika tanpa tujuan bersama karena globalisasi sudah menjangkau pada cara-cara berpikir generasi muda saat ini.

Berikutnya hasil wawancara dengan Pengerajin tenun ikat di Desa Ensaid Panjang kecamatan Kelam Permai diperoleh informasi bahwa dalam menekuni kerajinan tenun ikad tanpa adanya dukungan dari berbagai elemen tentunya tidak akan menjajikan suatu harapan tertentu. Dalam hal menekuni kerjainan tenun ikad selama ini dorongan yang sangat dirasakan kuat yaitu dari masyarakat sekitar yang bentuknya seperti penyediaan bahan tenunan yang alami dimana masyarakat sekitar yang tidak beraktivitas sebagai penenun memberikan andil yang besar selama ini.

Selanjutnya menurut pengarajin lainnya yang ditemui mengatakan bahwa salah satu aspek yang sangat penting yaitu 
lingkungan kerja yang sangat nyaman dan mendukung dan hal ini hanya dapat tercipta jika masyarakat sekitarnya memahami arti penting kelestarian budaya sehingga pemahaman terhadap nilai dan potensi budaya tradisional semakin tinggi. peran masyarakat atau partisipasinya juga dalam bentuk memberikan ide-ide dan solusi terhadap upaya menjalankan kegiatan aktivitas kerajinan tenun ikad yang sebelum adanya program daerah wisata hanya bersifat pemasaran seadanya sehingga dapat dikatakan tidak adanya propek bagi perekonomian masyarakat namun dengan adanya kebersamaan kerajinan tenun ikad dapat di lestarikan dan bahkan dapat ditingkatkan terus menerus samapai sekarang.

Berdasrkan hasil observasi yang diperoleh pada saat penelitian menunjukan bahwa secara nyata partisipasi masyarakat yaitu dalam menjaga lingkungan sosial dan lingkungan alam agar dapat menciptakan kenyamanan dan keamanan bagi pengunjung wisata alam dan wisata budaya. Selain itu dalam setiaop pelaksanaan kegiatan yang berskala besar masyarakat secara sukarela membentuk kepanitian agar dapat bertanngungjawab terhadap semua rangkaian kegiatan. terlihat juga dalam setiap bulannya tingkat pemesanan kain tenun ikad terus bertambah dan banyak pelaku penjualan produksi kain tenun yaitu kalangan pemuda melalui media dan juga organisasi -organisasi kemasyarakatan.

\section{Motivasi Masyarakat}

Berdasarkan hasil wawancara yang dilakukan dengan Kepala Desa ensaid Panjang Kecamatan Kelam Permai Kabupaten Sintang diperoleh informasi dalam perkembangan jaman yang semakin menuntut adanya kemampuan sumber daya manusia yang memiliki ketrampilan dalam mengolah hasil alam terdapat adanya keinginan atau motivasi yang berbeda-beda. secara khusus bagi masyarakat di Desa Ensaid Panjang motivasi masyarakat dalam mejalankan dan meningkatkan kualitas kain tenun ikad sesungguhnya karena sudah banyaknya permintaan yang datang dari berbagai daerah sehingga muncul harapan masyarakat bahwa kain tenun ikad dapat dijadikan sebagai salah satu sumber pendapatan bagi keluarga.

$$
\text { Motivasi ekonomi masyarakat }
$$
tentunya sangat mendasar karena hargaharga komoditas pertanian seperti karet saat ini mengalami penurunan harga yang relatif rendah sehingga diperlukan adanya tambahan penghasilan agar dapat membiayai berbagai keperluan dalam rumah tangga. Selain itu motivasi masyarakat juga terlihat dalam konteks keinginan melestarikan 
ketrampilan dan seni tradisionla yang sudah dikenal sejak dahulu dan untuk itulah pemerintah memberikan berbagai dukungan agar motivasi masyarakt selalu tumbuh dan berkembang tanpa harus berpatokan pada satu mata pencaharian saja. Selain itu keinginan masyarakat yang sudah baik saat ini juga tentunya termotivasi dari adanya harapanharapan untuk memperoleh konsep-konsep baru dalam mengembangkan kain tenun ikad yang berasal dari desa Ensaid panjang.

Berlandaskan dari hasil wawancara yang terhimpun dari kepala desa Ensaid Panjang dapat di deskripsikan bahwa keberadaan kerajinan kain tenun ikad yang masih berlangsung dalam masyarakat karena kuatnya motivasi dari sejak dulu hingga sekarang. Motivasi untuk terus menekuni kerajinan kain tenun ikad sangat dipengaruhi oleh kondisi sosial ekonomi di masyarakat karena pada saat ini tingkat harga hasil pertanian karet sebagai mata pencaharian utama mengalami penurunan sehingga masyarakat memerlukan adanya tambahan ekonomi untuk memperoleh hasil yang mencukupi keluarga kain tenun ikad menjadi pilihan disamping itu karena bahan-bahan bakunya tidak dibeli karena sudah tersedia secara alami di sekitar desa tersebut.

Selanjutnya hasil wawancara dengan Ketua BPD Ensaid Panjang Kecamatan
Kelam permai mengatakan bahwa sebagai pengarajin kain tenun ikad yang sejak dulu dilakukan tentunya sangatlah sulitberadaptasi dengan waktu dan keadaan dimana kain tenun ikad sebagai suatu produk masyarakat terkadang belum dapat dijadikan sebagai mata pencaharian, umumnya harga kain tenun ikad hanya sebagai penghasilan sampingan. Dalam kondisi yang demikian keinginan masyarakat tidak punah dalam menekuni kerajinan tersebut oleh karena itu dapat dikatakan motivasi dalam kebudayaan masyarakat sangat tinggi.

Informasi yang diperoleh dari Ketua Badan Permusyawaratan Desa Ensaid Panjang menyebutkan bahwa dalam prosesproses perkembangan kerajinan tenun ikad yang sampai saat ini masih ada dan berkembang tentunya karena adanya motivasi setiap masyarakat maupun individu, motivasi tersebut seperti motivasi untuk memperoleh hasil ekonomi, motivasi mengembangkan pretasi atau ketrampilannya, dan motivasi untuk melestarikan sumber daya tradisional. Motivasi-motivasi dalam masyarakat tersebutlah yang dapat mempertahankan kebudayaan yang bernilai tinggi dalam masyarakat. oleh karenya itu pemerintah sudah seharusnya memberikan dukungan yang kuat kepada masyarakat agar motivasi masyarakat dan pengerajin kain tenun ikad 
semakin tinggi.

Berdasrkan dari hasil wawancara yang telah terhimpun dari Ketua Badan PermusyawaratanDesaEnsaiddapatdijelaskan bahwa di dalam kebudayaan masyarakat terdpat adanya suatu motivasi yang sanbgat tinggi sehingga suatu kebudayaan dapat lestari dan dapat diturunkan kepada generasi selanjutnya. Motivasi tersebut tentunya datang dari orang tua yang memiliki keinginan agar kebudayaan dan tradisi terus ada. Selain itu dalam masyarakat Dayak khsusunya sistem sosialisasi kebudayaan secara langsung ditunjukan baik segi manfaatnya maupun segi religiusnya sehingga ketertarikan generasi muda untuk termotivasi sangat tinggi. Dalam konteks pemerintahan untuk mendukung motivasi masyarakat Badan Permusyawaratan Desa membentuk beberapa peraturan di desa agar apa yang dimiliki oleh masyarakat seperti pengetahuan tradisional menenun secara manual tersebut dapat terus terjaga dengan baik, regulasi terhadap pelestarian budaya sudah dilakukan dengan memberikan jaminan kepada masyarakat bahwa kerajinan tenun ikad dapat dijadikan sebagai aktivitas yang menghasilkan keuntungan ekonomi.

Berikutnya hasil wawancara dengan Ketua Adat desa Ensaid Panjang diperoleh informasi bahwa pada kultur masyarakat Dayak umumnya setiap kebudayaan tradisional yang memiliki nilai -nilai tradisi harus di wariskan kepada anak atau keturunanya, sehingga pola demikian terus berlangsung samaai dengan saat ini. Jika hal tersebut di kaitkan dengan motivasi tentunya banyak yang dapat dijelaskan diantaranya adalah bahwa pengetahuan dalam masyarakat untuk menghasilkan suatu karya yang nyata termotivasi dari keinginan menciptakan suatu ciri yang khas agar ada perbedaan dengan masyarakat lainnya. Selain itu dalam masyarakat untuk menunjang polapola kehidupan yang sifatnya sacral atau religious harus ada syarat-sayarat khusus yang dipercaya dapat memberikan dampak positif bagi kehidupan masyarakat, oleh karena itu karya kain motivasi awalnya karena untuk menciptkan suatu peradaban yang khas digunakan dalam berbagai acara yang khusus dalam upacara adat. Motivasi demikian tanpa pernah di duga pada akhirnya menjadi suatu kekayaan masyarakat dan daerah sehingga ada kewajiban bagi masyarakat untuk melestarikan dan mengembangkan pada tataran produksi atau untuk dijual.

Berikutnya menurut pandangan Ketua Adat Desa Ensaid Panjang dalam prosesproses kebudayaan yang ada di Desa Ensaid umumnya memperoleh perhatian yang cukup tinggi oleh generasi muda hal ini tidak saja pada kerajinan kain tenun ikad tetapi juga 
pada kerajinan-kerajinan lainnya yang belum terekspos di masyarakat seperti menganyam berbagai bentuk kerajinan tangan. Dengan mengacu pada kebiasaan tersebut jelaslah bahwa tumbuhnya motivasi pada generasi muda karena adanya keinginan yang kuat untuk tetap memiliki identitas yang jelas dalam masyarakat. Oleh karenya motivasi dasar yang telah dimiliki akan sangat bermanfaat jika hal itu dapat dikembangkan kearah peningkatan sumber daya manusia yang lebih trampil dan berpengetahuan.

Berdasarkan dari hasil wawancara yang terhimpun dari Ketua Adat dapat di deskripsikan bahwa dalam pola kehidupan masyarakat tradisional suatu ketrampilan dan pengetahuan dalam menciptakan sesuaitu yang bernilai harus diwariskan sebagai identitas yang menjadi ciri khas masyarakat dan daerah tersebut. pewarisan dari tradisi-tradisi yang sudah berlangsung lama tersebut termotivasi dari keinginan orangtua agar kelak generasi berikutnya dapat memanfaatkan nilai seni dan budaya untuk berbagai bekal bagi kehidupan setelah dapat hidup dengan mandiri, pada masa sekarang motivasi untuk melanjutkan suatu tradisi juga masih ada dalam diri orang tua namun yang lebih penting adanya motivasi di dalam diri generasi muda agar tradisi yang tadinya hanya untuk kepentingan upacara tertentu namun saat ini dapat dijadikan sebagai bagian dari produk yang bernilai ekonomi dengan tidak meninggalkan sejarahnya.

Dari kecenderungan yang berkembang dalam masyarakat saat ini menurut ketua adat bahwa pada masa yang akan datang tentunya harus diperkuat dengan keterlibatan pemerintah di dalam meningkatkan motivasi masyarakat sehingga aka nada banyak pengetahuan dan budaya atau tradisi pada masyarakat yang dapat digali sebagai bagian dari solusi memperbanyak lapangan pekerjaan. Dukungan pemerintah mulai dari Kabupaten hingga pemerintah desa akan sangat membantu masyarakat memahami nilai-nilai kebudayaan daerah yang bermanfaat secara nyata. Tenun ikad merupakan salah satu dari potensi yang ada dalam masyarakat namun masih banyak sumber potensi yang belum tergali untuk dijadikan kegiatan rutin dan untuk itu motivasi dari berbagai pihak sangat diperlukan.

Berikutnya hasil wawancara dengan pengerajin tenun ikad di Desa Ensaid Panjang diperoleh informasi bahwa motivasi masyarakat yang sudah terbangun seperti saat ini tentunya memerlukan strategi untuk menumbuhkannya, salah satu yang sering di sampaikan kepada generasi muda bahwa kerajinan kain tenun ikat merupakan bentuk kerajinan yang menjadi kisah nyata yang masih ada sehingga perlu mendapat perhatian jika tidak akan mengalami kepunahan. Selain itu 
menurut para pengrajin dewasa ini kerajinan dapat diandalkan sebagai salah satu aktivitas yang dapat mengisi waktu luang bagi generasi muda agar tidak mudah mengikuti pergaulan yang kurag bermanfaat.

Dari hasil wawancara yang terhimpun dari para pengerajin kain tenun ikad dapat dijelaskan bahwa untuk dapat melestarikan kerajinan tenun ikad motivasi generasi muda harus ditumbuhkan melalui berbagai cerita dan legenda masalalu agar dapat dipahami bahwa kerajinan tersebut merupakan salah satu bentuk kegiatan yang tidakboleh musnah sehingga sistem sosialisasi yang paling efektif yaitu di dalam keluarga itu sendiri. Pewarisan adat dan budaya atau seni sudah dilakukan secara tersistematis sejak dulu oleh kalangan orang-orang tua untuk tetap menjalankan sistem kebudayaan terlebih lagi hal-hal yang menjadi ciri khas suatu daerah tertentu. dengan demikianj diharapkan akan tumbuh kesadaran dari para penerus keturunan akan pentingnya identitas kebudayaan lokal bagi kehidupan dan keberadaan suku atau kelompok di daerah.

Berdasarkan hasil observasi terlihat proses pembuatan kain tenun ikad tidak saja dilakukan oleh orang-orang tua akan tetapi di kerjakan juga oleh generasi muda yang umumnya membantu, selain itu keterlibatan kaum pemuda juga dalam hal pemasaran dan dalam beberapa pameran yang sudah dilaksanakan baik di sekitar kota sintang maupun mewakili daerah ditingkat propinsi dan tingkat nasional. Hal itu menunjukan bahwa terdapat adanya motivasi yang cukup tinggi pada generasi muda sehingga motivasi tersebut merupakan salah satu potensi sumber daya manusia yang dapat dikembangkan dalam rangka mendukung pembangunan. Adanya motivasi juga merupakan suatu karakter dalam sistem budaya masyarakat kelompok etnik Dayak yang tidak saja dalam hal seni akan tetapi dalam kehidupan dan budaya sampai saat ini masih terus dijalankan.

\section{DAFTAR PUSTAKA}

Arikunto, S. (2007). Prosedur Penelitian. Jakarta : Renika Cipta

Hetifah, Sj Sumarto. (2003). Inovasi, Partisipasi, dan Good Governance. Yayasan Obor Indonesia. Jakarta.

Hamalik, Oemar (2008). Proses Belajar Mengajar. Jakarta : PT. Bumi Aksara.

Hasibuan, Malayu S.P. (2003), Manajemen Sumber Daya Manusia, Jakarta: Bumi Aksara.

Hendri, S. (2001). Manajemen SDM. Jakarta : STIE YKPN.

Lugiarti, Eppy. (2004). Peningkatan Partisipasi Masyarakat dalam Proses Perencanaan Program Pengembangan Masyarakat di Komunitas Desa Cijayanti. Tesis. Pascasarjana, IPB

Mardalis (2003). Metode Penelitian Suatu Pendekatan. Jakarta : Rineka Cipta.

Moleong, J Lexy (2005). Metodologi Penelitian Kualitatif, Bandung : 
PT. Remaja Rosdakarya.

Nasir, M. (1988). Metode Penelitian Jakarta : Ghalia.

Nimran, Umar. (1999). Perilaku Organisasi. Edisi Revisi. Malang : Citra Media.

Ndraha, Taliziduhu (1990). Pembangunan Masyarakat, Mempersiapkan Masyarakat Tinggal landas. Jakarta : PT. Rineka Cipta.

Notoatmodjo, Soekidjo, (2003), Pengembangan Sumber Daya Manusia, PT Rineka Cipta,. Jakarta.

Satori, Djama'an dan Aan Komariah (2009). Metode Penelitian Kualitatif. Bandung : Alfabeta.

Siagian, Sondang.P. (2009). Administrasi Pembangunan (Konsep, Dimensi dan Strateginya). Cetakan ke Tujuh. Jakarta : Bumi Aksara.

Sumardjo dan Saharudin, (2003). Metode-metode Partisipatif dalam Pengembangan Masyarakat. Jurusan Ilmu-ilmu Sosial Ekonomi Faperta IPB.

Soetomo., (2006), Strategi-Strategi

Pembangunan Masyarakat.

Yogyakarta: Pustaka. Pelajar.

Soetrisno, Loekman, (2001). Pemberdayaan Masyarakat dan Upaya Pembebasan Kemiskinan, Yogyakarta : Philosophy Press.

Slamet, Y. (2003). Pembangunan Masyarakat Berwawasan Partisipasi. Surakarta:

Sebelas Maret University Press.

Syamsi, Ibnu (1986) Partisipasi,

Komunikasi, Persuasi dan Displin dalam Pembangunan Jakarta: Rineka Cipta.
Uno,Hamzah. B. (2006). Teori Motivasi dan Pengukurannya, Jakarta : PT. Bumi Aksara. 